Anales de Literatura Hispanoamericana

ISSN: 0210-4547

http://dx.doi.org/10.5209/ALHI.58467

\title{
La redención en la novelística de H. A. Murena
}

Daniel Santana Hernández ${ }^{1}$

Resumen. H. A. Murena cultivó una novelística propia de su labor ensayística. Aunque parece clara la división en dos etapas de sus siete novelas, el conjunto de la prosa de ficción sigue una línea con afán escatológico: vencer el nihilismo pasa por anegarnos en él, sin perder de vista una particular noción de verdad soteriológica. La reflexión de Walter Benjamin en torno a la felicidad y la redención servirá de pilar maestro en el recorrido por las novelas del autor argentino.

Palabras clave: redención; felicidad; utopía; metáfora; nihilismo; ultranihilismo.

\section{[en] Redemption in H. A. Murena's novelism}

Abstract. H. A. Murena wrote his novels following closely his essays works. Although the separation between his seven novels in two phases seems clear, the whole of this prose works follows a escatologic goal: it deals with winning the nihilism suffering firstly. Walter Benjamin's thought on happiness and redemption works like the main key to cross the novels of the argentinan author.

Keywords: redemption; happiness; utopia; metaphor; nihilism; ultranihilism.

Sumario. 1. A locura, locura y media. 2. Semejanzas. 3. Representaciones de la felicidad. 4. El pasado. 5. A la sombra de la unidad.

Cómo citar: Santana Hernández, D. (2017) La redención en la novelística H. A. Murena, en Revista de Anales de Literatura Hispanoamericana 46, 391-406.

Que un desdichado se imagine la dicha nada tiene de singular.

J. L. Borges

\section{A locura, locura y media}

En la novela Polispuercón (1970) el personaje homónimo ordena a su equipo de gobierno aumentar la dosis de locura a los embates de caos fruto del pensamiento para, así, alcanzar la vigilia que la razón entorpece: más locura para despertar al fin". Esta "locura" supone el paso previo al resurgir de lo que Héctor Álvarez Murena (1923-1975) llama "Prehistoria" en la ensayística paralela a su ficción,

1 Universidad del País Vasco, España.

E-mail: elsantodani1977@yahoo.es

2 "La razón ha sido el gran engaño de la humanidad, inventada por malvados que quisieron mantener a los pueblos esclavizados y enloquecidos. Pero a locura locura y media" (Murena 1970: 26). 
estadio que amenaza a toda comunidad no constituida sanamente, "doloroso síntoma y desagradable índice de la enfermedad pasada y presente de la sociedad" (Murena 2002a:151). Acto seguido, dejar atrás una sociedad mortecina requeriría, según el dictador Polispuercón, multiplicar sistemáticamente la anarquía como vía de esterilización del Estado putrefacto. La vuelta a un estadio prehistórico despejará el horizonte para un nuevo despertar al romper los lazos con una Historia que oprime.

Este trabajo defiende la tesis según la cual la mencionada insistencia en el absurdo y la barbarie, el énfasis en el clima apocalíptico que empaña las novelas de H. A. Murena, obedecen a un proyecto redentor, a una visión optimista, si se quiere, harto difícil de captar en una lectura epidérmica que desatienda el resto de su producción como hipertexto ineludible. Para ello hemos de incidir en cierta dimensión teológica presente en su escritura de ficción, en concreto, en la presencia de una idea de redención derivada del pensamiento de Walter Benjamin que aportaría una nueva ventana interpretativa a la escasa bibliografía centrada en sus novelas. Consideramos que cierta perspectiva de la redención benjaminiana participa en la elaboración de la tríada de conceptos rectores de la teleología de Murena -"ultranihilismo", "subversión" y "transobjetividad"-, conceptos que actúan como ejes atravesando la escritura novelística para cumplirse (Esteban 2008: 195) por medio de los personajes y relatos.

Por estas razones, la obra de Murena supone un material privilegiado para repensar la franja que comprende desde el final de los años cuarenta hasta mediados de los setenta en lo que atañe a Argentina y el mundo occidental. El conjunto de las siete novelas publicadas en estas décadas se conforma de textos discordantes hasta la cacofonía, pergeñados con apariencia de impermeables al contexto más contemporáneo como pocos precisamente por orilleros. La contemporaneidad excéntrica que emana de sus palabras aspira, también desde la inmediata historicidad de sus personajes novelescos, a trascender lo contingente en virtud de "un pensar sobre las cosas que eluda la relación con el sujeto situado históricamente", en palabras de Domingo Ighina (2000: 247-252).

Tanto la llegada de Juan Domingo Perón y la sucesión de dictadores y presidentes electos en Argentina, a los que la escritura de Murena hace sombra, como el estallido de la Guerra Fría, la carrera espacial o el 68 allende las fronteras patrias están en las dos fases novelísticas del escritor, "Historia de un día" y "El sueño de la razón", figuran de forma subversiva, anacrónicamente. En la primera serie el reflejo de la descomposición del viejo mundo moderno sucede como un lento y suave murmullo ${ }^{3}$, una apuesta por una particular subversión de la novela hegemónica militante, aunque todavía según el molde realista. Para el dibujo del cataclismo prehistórico de "El sueño de la razón" los escenarios y personajes no son de orbe conocido -ni de este tiempo- y la lengua usada para contar sufre asimismo la metamorfosis fruto del caos, una transformación ineludible para la redención anunciada. Se trata de universos grotescos que no caben en nuestro

3 “[...] columnas imbatibles se resquebrajan hoy, caen, no con el repentino estrépito de los derrumbes exteriores, sino con el lento, suave, murmullo con que se agotan las impalpables esperanzas que sostienen la vida humana" (Murena 1961: 89). 
mundo, aunque funcionan como textos "mundanos"4; reproducen miméticamente a través de una suerte de escritura mítica, en consonancia con la premisa de Ezequiel Martínez Estrada cuando asevera que "nada más sensato que expresar hasta donde hoy sea posible (dentro de la red de ficciones en que nos hemos capturado) esa realidad en su connotación lógica: el mito y la alegoría" (1958: 35).

Murena nace como novelista acompañando a otros narradores que reclaman una "nueva realidad" alternativa a las representaciones de los escritores comprometidos; con este fin usarán el tamiz del mito y lo alegórico. Escribirán su propio realismo con lo inédito, lo onírico que los separa del examen superficial y los instala en un enclave desde donde practicar su personal método mimético con mayor fidelidad. Como "realismo de la decrepitud" (Rama 2008: 184) podemos completar la calificación de este singular quehacer novelístico del primer Murena y algunos de sus contemporáneos: aún se resisten a las maneras de lo fantástico, pero el naturalismo que rezuma verosimilitud enmohece en cuanto a efectividad representativa por lo que requieren de un discurso extraño que dé entrada a lo grotesco y deformado. Debido a ello, si bien los modos de escritura en América se importan de Europa, el escritor alerta en sus primeros ensayos sobre la complejidad de esta relación de dependencia, repensando a partir de arquetipos dos formas de asimilación de los bienes y prácticas culturales metropolitanas: el urbanita cómodamente instalado en una ciudad de formato europeo, de un lado y, frente a este, el nacionalista telúrico que reivindica la "barbarie" como idiosincrasia de la esencia americana, la precolombina. El juicio del novelista se ceba sobre todo con sus personajes urbanos, seres que portan la carga de decidir entre lo absurdo o lo cotidiano, la civilización o la barbarie, la caída sisífica o la anhelada redención.

Ejemplificaremos nuestra tesis escogiendo dos clases de escenas recogidas en algunas de las siete novelas, las que representan "felicidad" y las representativas de "pasado". Según la tesis II de Sobre el concepto de historia,

[...] en la representación de felicidad vibra inalienablemente la de redención. Y lo mismo ocurre con la representación de pasado, del cual hace la historia asunto suyo. El pasado lleva consigo un índice temporal mediante el cual queda remitido a la redención (Benjamin 1989: 178).

Veremos que lo alegórico y lo grotesco brilla en las escenas tratadas, haciendo de la narración un material semejante por perecedero además de por remitir a un original al que se asemeja. Cuando el coro final de Fausto anuncia que todo lo perecedero no es más que semejanza apunta, en opinión de Murena, a nuestra insalvable condición metafórica ${ }^{5}$. Apelamos entonces a un uso de la alegoría anejo más a la historiografía que a la retórica, como una imagen que se construye "diacrónica-narrativamente" con afán de claridad una vez se reconoce su gramática $^{6}$. Por eso el hombre debe lograr conciencia de su calidad de ser

4 Nos referimos a la expresión de Edward Said: “[...] los textos tienen modos de existencia que hasta en sus formas más sublimadas están siempre enredados con la circunstancia, el tiempo, el lugar y la sociedad; dicho brevemente, están en el mundo y de ahí que sean mundanos" (Said 2008: 54).

5 En la traducción de Rafael Cansino Assens: "Todo lo efímero/símbolo es solo" (Goethe 1943: 604).

$6 \quad C f$., idea de "alegoría" pergeñada por Paul de Man en "La alegoría de la persuasión en Pascal", (De Man 1998: 77). Con agudeza se pregunta De Man más adelante: “[...] ¿por qué las verdades más importantes sobre 
metafórico, ha de ser metáfora. En la novelística mureniana, narradores y protagonistas, con su prosa, con sus gestos, frisan la muerte y remiten a otra zona, perecen y simbolizan, desde la felicidad o desde el cuento del pasado.

La tesis III vale como complemento de la anterior al rescatar una concepción del cronista que yacía latente en la modernidad, sepultada por la confusión del término con el de historiador académico como el que se limita a registrar la versión hegemónica:

El cronista que narra los acontecimientos sin distinguir entre los grandes y los pequeños, da cuenta de una verdad: que nada de lo que una vez haya acontecido ha de darse por perdido para la historia. Por cierto, que solo a la humanidad redimida le cabe por completo en suerte su pasado (Benjamin 1989: 178, 179).

La función de los narradores en "El sueño de la razón" se cumple si ejercen de cronista, de aquel que anticipa el juicio final cuando narra la historia integralmente, cuidando al máximo de no saltarse los acontecimientos aparentemente ínfimos relativos a los humanos tratados como irrelevantes en la sociedad (Löwy 2002: 63). Inspirado por las tesis del pensador berlinés, que traduce y publica a principios de los años sesenta, Murena escribe su ficción sobre hechos intrahistóricos, en la penumbra de los avatares reconocidos por la historia oficial. Su voz novelística marca un camino con un objetivo señalado y, afín al filósofo del futuro que según Nietzsche se preocupará por lo sagrado, el novelista narrará apoyado en lo intrínsecamente religioso, desde y para la fe, como un "ateo, pero un ateo a la espera de un dios que todavía no se ha mostrado" (Strauss 2007: 97), como el bárbaro que espera redimirse escapando del anatema del absurdo.

\section{Semejanzas}

El diario argentino La nación publica el 4 de junio de 1950 un artículo al que quizá no se le haya prestado la suficiente atención. Nos referimos a "El café", breve ensayo donde Murena esboza un símil para su teoría crítica a partir del espacio de los cafés que siembran el centro de Buenos Aires ${ }^{7}$. Según el autor, este escenario heredado de la Europa refinada se consagra en última instancia al tratamiento azaroso de las cuestiones abstractas propias del ágora ciudadana. Que exista un ámbito con este fin delata la superación de la animalidad humana y la consiguiente entrada a un mundo ignoto, precario y seductor, el mundo de la inteligencia, orbe que, no obstante, conserva jirones de las verdades de los intereses naturales.

El café en el Nuevo Mundo -un pequeño local en Buenos Aires- invita, al contrario que en su ascendiente europeo, a lo precario, seductor y desconocido evitando el diálogo con los vecinos y guareciéndose en el silencio. Para el escritor, el mutismo que encierra al parroquiano de un café porteño abriga el sentimiento religioso que se superó (o reprimió) en la desarrollada metrópoli. Si en un café de

el mundo y sobre nosotros mismo tienen que plantearse de soslayo, y de un modo referencialmente indirecto?", ibid, p. 79.

7 "El café", Espacio Murena: http://www.espaciomurena.com/?p=2849 (el 12/2/2014). 
París las mesas hacen de ágora donde se discute, en América funcionan como escenarios para el encierro en uno mismo, a saber, el café como templo laico donde buscar a Dios y lugar donde experimentar el miedo a las cosas sin nombre. La lengua que funcionaba al otro lado del Atlántico se torna entonces estéril para confrontar la experiencia americana. Pero lo americano en Murena evoluciona a un problema universal y, si "El café" dramatiza el reencuentro con lo innombrado del europeo en América, esta cita es metáfora de la búsqueda incesante del hombre de su hogar originario que, en Murena, se cristaliza en otra lengua para denominar un mundo redimido.

La cartografía del café de Murena ilustra la sinopsis de su pensamiento: dibuja una ventana (o su apelación) abierta a la calle, a la vida, a la esperanza; también están los billares, la baraja, el juego, rincones que delimitan el infierno. Hacia fuera se proyectan anhelantes quienes buscan lo divino para salvarse. El otro bando alberga a los desesperanzados que se regodean en la oscuridad. Murena considera que tanto la ventana como el juego funcionan como polos necesarios del sentimiento religioso; confía en un encuentro en el punto equidistante redentor donde finalmente se morderá el mundo, "cuando hayamos forjado nuestras palabras para las cosas que laten en la calle, para la vida, cuando empecemos a comprender a las fuerzas que nos rodean, a confiar en ellas" 8 .

Puesto que en el infierno figuran los embargados por el absurdo y la cotidianidad y, agrupados en torno a la luz de la ventana, esos que esperan poder saltar a la calle para redimirse en el encuentro, podríamos valorar ambos espacios dispuestos escalonadamente. Antes, el infierno; y, la mancha de luz cerca de la ventana, la fase posterior, superior. En suma, el lar de la decadencia, el absurdo y la barbarie como paso previo para acercarse a la ventana, la vida.

La Historia reciente confirma la evolución bipolar escenificada en "El café". Tras la Ilustración, el sentimiento decadente se convierte en la nueva pauta que guiará a los historiadores de finales del siglo XIX, confluyendo en sistemas teóricos que reivindican otra idea de progreso fatalmente derivada del declive al que está destinada toda civilización. Sin embargo, las ideas historicistas a la sazón mudan de piel manteniendo la esencia teológica y la sustancia teleológica propia únicamente de un pensar religioso. Las teorías marxianas y el resto de formulaciones que pronostican un final, cualquiera que fuese, no dejan de funcionar como una versión atea de la "voluntad creativa" tal idea bíblica (Wolin 2003: 122). Aunque cuidado con tratar la impronta teológica residual cual puro lastre, como apunta con agudeza Lionel Trilling: "[...] la religión, al declinar, deja un detritus de piedades y de vigorosas presunciones, que provee de una condición particularmente afortunada para ciertas clases de literatura", que imprime, añadimos, una huella de trascendencia, la intención de verse más allá del puro presente de la escritura y la lectura.

El aliento pesimista finisecular se agrava en los años siguientes, con especial énfasis en la segunda posguerra mundial. Contra esta tendencia y con la misma intensidad se extienden los credos utopistas que confían en la revolución, en el papel central del hombre como su propio salvador. "La historia se endereza" según

\footnotetext{
"El café", op. cit.

Lionel Trilling comenta una idea del poeta Allen Tate (Trilling 1971: 337).
} 
estos, pero Murena desconfía: “¿El hombre? Acabáramos... El hombre como sujeto de la historia: Karl Marx” (Murena 2002 a: 79).

La verdad es que el mundo quedó lejos de redimirse tras el proyecto iluminista. Ciertamente se produjo un desencantamiento al desactivar las fuerzas de los mitos, pero entre redención y desencanto media otra lucha. Rescatando el germen de nuestra tesis, la idea de redención de Walter Benjamin rebosa intencionalidad política al subrayar la diferencia entre desencantamiento y redención, imprimiendo, además, particular énfasis en el convencimiento de que la lucha contra las injusticias (la búsqueda de un mundo redimido) debe radicar en un apriorismo insalvable: tratar la injusticia exige creer en la esperanza (Mate 2006: 24).

En 1951, "Homenaje a las lenguas", recogido en su primer poemario La vida nueva, cuenta el desmoronamiento del verbo al recalar en el sur, "los idiomas se tornan sombríos y procaces como criminales/[...] sobre estas largas y fragrantes tierras no tocadas" (Murena 2002b: 469). El poema incide en el esquema de "El café":

Hasta mi habitación suben en el crepúsculo como turbias imágenes del hombre: los idiomas deformes, el rumor de la fiesta sexual, los gemidos del tango, el son monótono y cruel de las manos, todos los dialectos del mal, me asedian, y entre la triste algazara que sube y el silencio que se cierne yo tengo que pronunciar con pasión mi nombre, para saberme, y entre las dos sombras darme luz, confirmarme (Murena 2002b: 469,470).

La estrofa expresa la escena que se dibuja en el café donde el ser silencioso oscila entre la ventana y el juego, impotente para la decisión. La verticalidad de la jerarquía platónica que hereda el judeocristianismo funciona perfectamente en la asignación de valores en el poema. En la mitad de encuentro de los polos antagónicos la voz lírica sufre sendos extremos. La estrofa bosqueja la escena que se dibuja en el café donde el ser silencioso oscila entre la ventana y el juego, impotente para la decisión. En el poema, desde abajo (el fondo, la oscuridad) asciende lo que no sugiere más que ruido informe; por arriba la voz siente el peso del silencio, que se cierne sobre él. Las lenguas son "humos" que desembarcan en el "sur" y "descienden como reyes heridos/ sobre el seno de silencio de sus playas" mortecinas (Murena 2002b: 469) a la vez que letales, se enredan en vano entre sí.

Hagámonos cargo también del título del poema. La tentación de una lectura irónica se antoja irresistible, es cierto; aún así, entre el silencio (de pronto como la agrupación de las lenguas en una que no lo es, como el blanco para la gama de colores) y la algarabía babélica de las lenguas, Murena nunca se pronuncia. En el fragmento anterior parece que la tendencia se inclina del lado del nombre (el lenguaje, el rumor, los gemidos, los dialectos del mal), que le confirma y lo alumbra. Pero también pudiera referirse a una estancia en el medio, sitio donde la tensión de los polos apenas le permite balbucear: yo, yo... 
Yo, previamente de una raza antigua como el tiempo,

Que alguna vez alzó sólo el profundo zumo de la dicha en su canto,

Yo, doctor ahora de amarga sabiduría,

Conozco también los idiomas aciagos,

Entiendo sus cifras, frecuento sus sumidos laberintos,

[...] (Murena 2002b: 470).

Articularse a través del "yo" pudiera ser el requisito para manifestar la duda y la Caída, es decir, quién duda y cae. Pero nada más. Tantear el silencio balbuceando la primera persona es hacer equilibrios en el arco que generan las sombras; es conocer que la Ausencia nos envía a algún lado de donde nos trajeron y adonde queremos regresar. Pero cómo lo nombramos, y qué hablamos en ese nuevo lugar: cuál es la lengua de la redención, ¿qué idioma manejan los redimidos? ${ }^{10}$

El origen de la cultura (el yo que balbucea) surge obedeciendo al humano empeño de cubrir el silencio, que es presencia sagrada. El silencio divino cuando es reconocido en vida puede agostar, quemar, anonadar, pocos lo toleran (Murena 2006: 116), "La cultura alza así con "la palabra", o sea con sus infinitos medios de acotación y población del silencio, la casa del hombre [...]" (Murena 2006: 117). La disyuntiva que se erige entre tapar la ausencia de verbo y perderse en este se recrudece en la época de escritura del poema, un tiempo de crisis que anhela volver a oír el silencio y que brinda la atmósfera adecuada para su mejor interpretación, esperando la "forja de una palabra más exacta" (Murena 2006: 118). Si se vuelve patente que el conocimiento ha resultado estéril en su labor de combatir la angustia (la angst genuina de la época) el poema termina invocando el silencio, su vuelta, "para que caiga con sus armas/ sobre los idiomas agonizantes, sobre mi nombre", y

Sobre ellos, sobre esas ruinas, asentará sus alas el misterioso pájaro invisible del silencio de cuyo pico sale la voz nueva como de algunas muertes otra vida (Murena 2002b: 470).

En opinión de Murena, Horacio Quiroga se convierte en uno de los pioneros de un nuevo nombrar o de un nombrar otro que se antoja necesario. El nuevo verbo debía adecuarse fielmente a la aún innombrada realidad americana, designada hasta entonces con el lenguaje de Europa, "ese fácil camino del espíritu" que encubría el horror (Murena 2006: 77). Y el horror debe ser descubierto y nombrado, para humanizarlo, para conjurarlo. Pero la nueva lengua debe arribar después del silencio, cuando se desmantele la palabra forastera.

[...] a medida que los estremecimientos que narra son más entrañables, mayores deterioros va sufriendo la escritura, el estilo, como si un monstruo impalpable se lo fuera devorando sin remisión. Lo que le comía las palabras, el estilo, era lo que le iba comiendo la vida (Murena 2006: 79).

10 La Vita nova de Dante, evidente referencia del poemario de Murena, se apoya en el toscano, balbuceo incipiente del latín; ocho siglos de por medio y en un mundo nuevo el autor bonaerense se verá impelido a regresar en busca de un idioma en estado de gestación que, posiblemente, se encarne en Folisofía, su obra póstuma. 
El análisis de Quiroga y su obra, ambos un mismo cuerpo, se ha transformado con el tiempo en un posible autoanálisis del comentarista, que en el mismo texto sentenciaba que somos selva, porque todavía no hemos conseguido entendernos, hablarnos (Murena 2006: 81). Para lograrlo, para redimirnos, el temprano pensamiento de Murena aboga enérgicamente por la inaplazable aceptación del pecado.

La tradición judeocristiana, a la que pertenece Murena -miembro, eso sí, de "las tropas irregulares de la civilización" ", ha sido garante de una idea de redención que sigue presente, disfrazada de filosofía de la historia, en el proceso de secularización de las disciplinas humanísticas. Redimir (salvar, ayudar, librar) se redime del pecado a fin de curarnos, tanto desprendiéndonos de la miseria espiritual cuanto adquiriendo todos los bienes escatológicos ${ }^{12}$. Siendo así, desde dónde se redime, qué o quién nos salva. El concepto de redención propio del cristianismo contesta de distinta forma a la cuestión según recurramos al Antiguo o al Nuevo Testamento. Desde aquel la acción redentora nace fuera del hombre, solo es posible como acto divino, directamente desde Dios o mediante sus enviados. Los Evangelios y Pablo, por su lado, contemplan a Jesús de Nazaret como único salvador posible, y toda la doctrina redentora emana del comentario a gestos y palabras del Hijo. Ambas vertientes generan en la redención cristiana (siempre escatológica) una contradicción que ejerce de motor, sin la cual su necesidad desaparece: estamos ya redimidos para la esperanza de que algún día nos salvaremos, "para que podamos esperar, hemos sido salvados"13. Entonces, según la doctrina cristiana, la metamorfosis buscada en la redención se posibilita con una vida sacramental y su inherente vida simbólica; contrariamente pues una sociedad secular "tiene necesidad de desmarcarse de los extranjeros y de los enemigos, y no pueden fundar su unidad más que a expensas de algún chivo expiatorio" (Lacoste 2007: 1117). Walter Benjamin y Héctor Murena discrepan, postulando por igual una redención posible en y desde los hombres, una salvación autosoteriológica (autónoma de la persona) mas no laica, aún religiosa por conservar la vida simbólica.

Murena, concretamente, como pensador fue un filósofo de la historia que teorizó asistemáticamente desde un prisma religioso, que construyó mundos narrativos fieles a la falta de coherencia sistemática de su ensayística en busca de dicho renacer; espacios de ficción en los que, agazapada bajo la escritura grotesca, la teología, pequeña, fea y recelosa de su invisibilidad sostenía el discurso otorgando sentido -una mirada a un mundo redimido- al aparente pandemónium delineado en las historias.

Porque, en realidad, considerar la idea de redención significa de antemano hacernos cargo de la inmanencia de la esperanza en toda escritura, que por definición es proyecto, por vocación teleología y, en origen, mesiánica debido a su voluntad de espera. Si para Walter Benjamin teología implicaba tanto rememoración como redención mesiánica, en Murena se traduce fundamentalmente en este segundo aspecto, como espíritu necesario para salvar(se) (d)el nihilismo y

\footnotetext{
Expresión de Isaiah Berlin para referirse a J. G. Hamann (Berlin 1997).

"Redención" (Bauer 1967: 878).

"Salvación", a donde remite "Redención" (Lacoste 2007: 1109).
} 
regresar redimiéndonos a la Ciudad Ideal anunciada desde el mesianismo. La bifurcación o polaridad es también compartida por ambos pensadores. Una mirada enfoca al encuentro del nombre con la cosa, de donde fuimos traídos -"hemos sido llevados (fero) más allá (meta)" (Murena 2002b: 444)-, desde allí hasta aquí. Hacia otro lado, Murena y Benjamin divisan un camino que no guía, "que nos mantiene en el territorio de la irreparabilidad"14. La metáfora (la semejanza, el símbolo) desempeña así para el escritor argentino el rol de piedra de toque del espíritu redentor y la contingencia histórica. Se trata en suma de un logocentrismo donde insólitamente el logos no es más que una cadena interminable de metáfora/semejanza y el hombre -ya lo dijo Martin Heidegger-, un mero instrumento de articulación.

"Nos dejamos poseer por el lenguaje tardio, caído" (Murena 2002b: 446). Por ello el ultranihilista tiene la función de superar la caída y su lengua recordando su carácter efímero y simbólico, percibiendo todo como semejanza. Tal es la visión transobjetiva: la que salta por encima del eje objetividad-subjetividad visionando otra forma de conocer que remite siempre más allá, a otra metáfora, a un vertido infinito de sentidos en una traducción sin fin. La vía que despeja la transobjetividad, ni juego ni ventana, subvierte los patrones epistemológicos dominantes. El intelectual tiene que practicar la subversión bajo este postulado, desde una periferia ucrónica que guarda distancia con todo credo oteando desde el extrañamiento del que sale de lo histórico, para, al fin, diseccionarlo ampliando el margen.

Y es por este sendero por el que se puede aspirar a la redención. Ahora bien, representar la felicidad y el pasado de aquellos que no fueron felices ni estuvieron, es un requisito insalvable para emprender el camino de regreso.

\section{Representaciones de la felicidad}

Las narraciones de Murena pueden recibir sin paliativos el calificativo de desdichadas. Con todo, se reservan escenas en las que los personajes parecen disfrutar de una aparente coyuntura de felicidad. A continuación presentamos dos momentos susceptibles de describirse como felices para los protagonistas. Ambas escenas constituyen la conclusión de las dos series novelísticas, aunque es cierto que Murena había proyectado tres libros más para el grupo de "El sueño de la razón", cerrado por la muerte del escritor. En cualquier caso, el cierre de Folisofia conserva el grado de contundencia propio de un punto y final definitivo.

Al término de Los herederos de la promesa (1965), tercera novela publicada y corolario de la serie "Historia de un día", el protagonista da un giro a su existencia aceptando las responsabilidades sobrevenidas que en un principio esquivaba desde su postura nihilista. Juan Forn pide que Clotilde, la mujer que le hará padre, le vuelva a tender la mano para finalmente salvarse. Con este gesto actúa como la culminación de una serie de maneras y comportamientos de los personajes principales de la trilogía, seres que encarnan en gran medida al arquetipo del urbanita aludido más arriba. Clotilde, por su parte, representa la posibilidad de

14 Reyes Mate citando a Ricardo Forster (Mate 2006: 28). 
felicidad, como contrapeso a la negatividad que hasta ese instante ha desbordado el protagonista, a quien libera y redime:

De pronto algo se resuelve en mí. Una imagen despierta, crece. Me sacude -es la cara de Clotilde. Me pongo de pie. Camino, rápido. Mirando a ambos lados, buscando algo. Un teléfono. Más rápido. Cruzo la calle. Entro a un bar (Murena 1965: 324).

Una epifanía desencadena la resolución de Juan de apostar por el amor y la familia. Logra con este impulso desprenderse de los lazos que lo esclavizaban a la supuesta originalidad del héroe de la novela contemporánea, el antihéroe. Este ha de eludir (antiheroísmo obliga) la repetición inevitable en la que todos caen, la procreación; y desafiar, fiel a lo que ya es una tradición del antihéroe, al comme il faut impuesto. Pues bien, Juan Forn se libera de la imposición del papel de antihéroe y acepta la vía redentora de la filiación y la familia ${ }^{15}$. Esto supone sin duda otra afrenta al arquetipo nihilista -que debe despreciar el futuro por irreal- ya que actúa, elige en pos de un futuro determinado. La representación de esta escena impide una envidia o arrepentimiento posterior respecto a la felicidad que hubiéramos podido disfrutar, "entre las mujeres que hubiesen podido entregársenos" (Benjamin 1989: 178). Gracias a este corolario "vibra inalienablemente la redención" (Benjamin 1989: 178).

He elegido. Marcho a buscar el alimento del que se adelanta a su derrota. Porque es necesaria. Tal vez no lo sea. Tal vez sí. Pero yo la necesito. Sé que debo hacer lo que estoy haciendo. Todo debe cumplirse. Sería falso que siguiera huyendo. Apareció y dijo: si quieres sígueme [...] Todo se terminó: todo empieza. La salida está justamente allí donde no hay salida (Murena 1965: 324).

Juan Forn se desprende por otra parte de la ironía que lo ha desgastado durante toda la narración, su narración. Se cierra así la historia de ese día poliédrico, desplegado en tres libros y escaso de alusiones a la alegría de la vida, con una asunción que promete la redención desde una escena de felicidad. El hecho de escoger convivir con Clotilde y su futuro hijo altera la mirada, que pasa de fenoménica a una mirada amistosa logrando ver los árboles como árboles, dejando de ser un "místico sin objeto de adoración" encerrado en su arca de silencio para traspasar la ventana del café y acceder al mundo. Como si el hombre del café saltara por la ventana, Juan tartamudea "para mostrar el palacio del día. Pero ella no necesita más, no hace falta otra elocuencia" (Murena 1965: 325), se aleja del silencio incólume cultivado en su refugio y muerde el mundo con esa extraña lengua, que no llega a ser, y todo terminó, todo empieza.

En Folisofía (póstuma, 1976) Dagoberto renace después de una dolorosa estancia en el hospital. Su nueva condición de tuerto le lleva a recapitular y hace así balance del momento presente:

15 Para esta reflexión me apoyo en las ideas de filiación-afiliación desarrolladas por Edward Said en "Sobre la repetición" (Said 2008). 
Los años esperitualizaron la mi folisofía [...]. Mencionaré nonostant que el amor fízole tocar las cimas de las cimas. Travail costóme remontáreme supra la realitat. Poroque la mojier dama de la que me había me enmorado, cascuna vez que me la dirigía con el parol descíame:

-¡Sal, tuertín!

Et con un sorrís dejaba me planctato n la vía (Murena 1976: 127,128).

En este caso, el protagonista pretende tras la cruda experiencia de perder un ojo superar la realidad mundana, alquila una casa alejada del tumulto y utiliza el enamoramiento para impulsar la ascensión. Aún así, su amada lo rechaza por un tiempo hasta que ella misma contacta con él rindiéndose a sus sentimientos. Cuando finalmente lo llama, Dagoberto experimenta la auténtica y definitiva ascensión: “¡Foerza de la mi folisofía! Resalí del dolore pureficado coal la ave que apélanla fenise si saca acua del fuego" (Murena 1976: 129). Este desenlace refleja la despedida de un narrador feliz que, con todo, clausura la historia con un final abierto en el que las golondrinas se alejan en el otoño, anunciando el invierno. De hecho, las cuatro estaciones están presentes en algunas de las narraciones novelescas y con su circularidad simbolizan una transición de eterno retorno en las vidas de los personajes relevantes. El desenlace feliz de Folisofía en pleno otoño hace presumir una secuela de desdicha.

A pesar de ello Murena no se resiste a representar la felicidad como culmen de la vida que se nos da a conocer de manos de su propio protagonista. Un protagonista perfectamente susceptible de calificarse como estereotipo del marginado y del marginal, lumpen, pícaro y trapero. Con este ejemplo, pues, podemos percibir el tratamiento de un instante feliz gozado por un miembro periférico de la sociedad. Consecuente con las tesis benjaminianas, el escritor argentino brinda un papel al pequeño, dando cuenta de la verdad, buscando una vez más el aliento redentor. A esto debe añadirse que se trata del mismo marginado quien cuenta su vida picaresca, quien hace de cronista de las inclemencias que sufre, por medio de, eso sí, un lenguaje deformado, o conformado con jirones de castellano diociochesco, de retazos de español americano caricaturizado y restos de latín macarrónico. Ahí podemos ver a Murena bajo el disfraz de pícaro travieso, buscando el lenguaje semejante, el idioma que quiere decir pero que desdice, más bien, con la articulación del balbuceo y la onomatopeya.

\section{El pasado}

La contraportada de la primera edición de Folisofía se pronuncia sobre la prosa de la novela juzgándola como una parodia de la parodia, muy extendida en esos años: "lleva a la exasperación la manía paródica de la literatura de nuestro tiempo. [...]

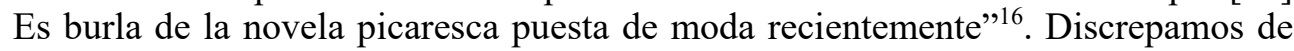
este punto de vista. Hay en el estilo de este libro, como en el del resto de los que forman "El sueño de la razón", la consecuencia de un proyecto de escritura en el que el hacer novelístico invierte cronológicamente la evolución del género, a saber:

16 Contraportada de Folisofía. 
de la prosa convencional y realista de las primeras entregas se evoluciona al código protonovelesco de las obras de los años setenta.

La representación del pasado practicada por Murena novelista, teniendo en cuenta lo dicho, se podría interpretar desde tres perspectivas. Evidentemente una de ellas pasaría por considerar cada narración como testimonio, es decir, información de un tiempo pretérito; las siete novelas entran en esta clase. Otra forma de apreciarlo radica en buscar historias que ilustren un tiempo pasado considerado como histórico, es decir, que trabaje con material reconocible por el lector como acontecimientos consignados por el relato oficial; "Historia de un día" muestra de esta manera un escenario de enfrentamientos callejeros y convulsión política tal como sucedieron en los años del peronismo. Por último, también creemos que funcionan como representaciones del pasado las obras escritas con estilo y maneras tal como se pudieron escribir en otro tiempo. Nos fijaremos en esta perspectiva con dos ejemplos de la segunda serie.

En la tetralogía el uso del código denominado carnavalesco por Mijail Bajtín, apunta a una transgresión de ecos vanguardistas a través de la regresión a los principios de la historia de la novela; así, encontramos una pauta para invocar lo pasado: con la forma. Y esta opción de narrar antigua, cuando no arcaica, reivindica el modo de contar del cronista que deleitaba con el recuerdo antes de la llegada del historiador profesional. Recordemos que el cronista "da cuenta de una verdad: que nada de lo que una vez haya acontecido ha de darse por perdido para la historia" (Benjamin 1989: 50).

La narradora de Caína muerte (1971) se hace llamar "la cronista", una suerte de máquina que por momentos se califica también como poeta de inspiración homérica ("Conchita posee tanto de humano porque es el vaso que guarda y canta acontecidos dramas del hombre que los hombres le entregaron en custodia" (Murena 2002b: 50)) y de archivista que, además, "aún me remonto a la esencia de las historias y vuelo, por aquello llamado honestidad o vocación o cretinismo concentrado" (Murena 2002b: 47) ${ }^{17}$. Conchita es tanto narradora como personaje, un personaje que no participa en la historia, pero que figura, al representar al cronista e interlocutor que le cuenta al lector, instancia que interpela en todo momento.

Con Caína muerte Murena repite un modelo - practicado con la obra anterior, Polispuercón, de 1970- de extraña distopía que oscila entre un mundo medieval y los parámetros de la ciencia ficción, un subgénero que despunta en esos años. En virtud de tan enrevesada parodia, no es complicado detectar una posible búsqueda de una cita secreta entre el pasado y generaciones contemporáneas o futuras. El escenario de la novela pudiera ser una aldea con su plaza y calle principal trufada de personajes típicos de un burgo del Medievo. Pero este espacio acoge elementos anacrónicos como la misma máquina narradora o artefactos mecánicos giratorios, convirtiendo la novela en una particular historia de ciencia-ficción. En este caso el ejemplo elegido no se refiere tanto una escena particular sino la labor del narrador al ser la misma obra la "escena" que representa el pasado, en su fondo y en su forma y que, simultáneamente, representa el encuentro entre generaciones que propone el pensador judío en su tesis III.

17 La cursiva es nuestra. 
Algo más delicado es hablar de una representación del pasado en Polispuercón. El libro cuenta el ascenso al poder del narrador que manipula al sátrapa del momento para que adopte las decisiones que aquel considera, dominando en la forma de gobierno una descarnada política de terror. El argumento propio del subgénero de las novelas de dictador ya invita a contemplar la obra como posible ejemplo para apoyar nuestra idea. Ocurre que la representación de tiempos pretéritos en Polispuercón, como en toda la tetralogía, se da en clave alegóricocaricaturesca, y bascula por ello en la indeterminación entre lo que pasó y lo que puede repetirse. Ya que, lo que se lee por hiperbólico o pasado por el filtro de lo caricaturesco, tal vez es pura verdad, representación, auténtica mímesis de lo que sucedió, fue o es: el derecho de pernada (p. 9), la mutilación como tortura (p. 10), el que:

[...] durante una de tantas revoluciones, al consumarse en una plaza la masacre de decenas de personas, ellos, mientras observábamos la escena, en lugar de detenerse en los pueblos tendidos, me hicieron admirar la hermosa sinfonía de colores que los charcos de sangre componían sobre el césped. (Murena 1970: 11)

O la invención de un chivo expiatorio para unir a la población a favor del dictador y contra el extraño (p.100). Esta enumeración de barbaridades brinda una somera muestra de los múltiples rasgos de realidad que escenifica la historia de Polispuercón, válidos como casos de representaciones del pasado o de mímesis de acontecimientos potenciales.

Los mencionados tratamientos del pasado cargan con una intención de aviso para navegantes. Esos existieron, los represores y los reprimidos. Es necesaria la crónica de las hazañas de unos y de otros para que nada se dé perdido por la historia.

\section{A la sombra de la unidad}

Tantos años sin salir de las vísperas, uno se cansa de esperar.

J. L. Borges y H. S. Muchnik

Locura y media. En efecto, a medida que nuestro novelista publica novelas el exceso de violencia y desenfreno moral se intensifica. En una ocasión llegó a confesar: "Mi ideal sería escribir con insultos la más maravillosa historia de amor", o

Quiero que tras ese lenguaje que se destruye a sí mismo el lector sospeche constantemente la presencia de un vacío absoluto, que lo inquiete y le transmita una realidad superior a él. Ahí tiene otra vez lo religioso, en el lenguaje (Murena 1992: 20).

El ciclón apocalíptico de sus textos se esfuerza por hacer honor a su propio juicio de la contemporaneidad, que entrona lo útil y desecha los dioses, el amor, la 
esperanza. Igual se describe el Bajo Medievo ${ }^{18}$, inspirador de las narraciones tardías murenianas, y "por tales ausencias concluye el mundo cotidianamente en un desastre [...]. El apocalipsis: de eso huimos en razonables máquinas enloquecidas" (Murena 2002b: 419). Después, la Historia, posdiluviana, posible exclusivamente en tanto espejismo, nutriente de esa esperanza enfocada en un último significante que dé paz a la búsqueda del ser.

Todo lo existente es traducción, dice el autor desdichado (Murena 2002b: 447), puesto que todo es perecedero $\mathrm{y}$, consecuentemente, semejanza. La única forma de ser plenamente, de ser redimido -de redimirse, de ser- estriba en el continuo movimiento hacia donde nos empuja la referencia del símbolo que somos y que todo es (Jacques Derrida diría que todo es metáfora menos el verbo ser (Derrida 2012: 16)), referencia esta que volverá a remitir incansablemente a otro, y a otro lugar. Merced al envío eterno siempre se puede ser mientras se viaje, mientras se traduzca enfocando a la unidad inalcanzable para lograr al menos acceder a su sombra:

[...] qué es lo absolutamente intraducible que permite y reclama la posibilidad y la práctica infinitas de traducción? Lo absolutamente intraducible es la Unidad perdida, que la traducción recuerda con su incesante esfuerzo por reunir cosas convirtiendo unas en otras (Murena 2002 b: 447).

La literatura, particularmente aquella que se aleja del realismo acuñado como genético ese que no duda de la existencia de una realidad única a la que el lenguaje etiqueta ${ }^{19}$ permite más espacio de viaje entre sentidos y por lo mismo más plenitud de ser. Coincidimos con Patricia Esteban en su juicio al respecto: en el lenguaje literario (en ciertas clases de literatura -en palabras de Lionel Trilling-) se encarna la vitalidad de una nueva lengua (¿el balbuceo?, ¿la onomatopeya?, ¿otra mudez?) que permitiría volver al presente de los orígenes (Murena 2012: 16); un abordaje "clásico" de lo literario donde el desbordamiento de la representación brindaría el espacio para que lo humano se represente ${ }^{20}$. Por todo esto las representaciones literarias de la felicidad y del pasado abogan por una promesa de vuelta -si la palabra actúa de buena fe, "puede prometer una manzana, un amor, una paz" (Murena, 2002b: 448)-, de progreso que genuinamente es regreso.

Regreso, o desandar el círculo desde el momento apocalíptico que encarna la novelística mortecina del último Murena (ficción que revela, escritura visionaria "por medio del acto último de todas las objetivaciones, la destrucción" (Barthes 2005:14)); una travesía con destino a otra génesis donde se recomienza con la acción de nombrar en esa nueva lengua.

Para dilucidar la perspectiva de la Ciudad Fiel, la Ciudad Ideal, el punto de nigredo del que habla la alquimia avisará de cuál es el momento crítico, por visionario, y la escritura se

18 "Es el gran sabbat de la naturaleza [...] las estrellas caen, la tierra se incendia, toda vida se seca y muere. El fin no tiene vida de tránsito o promesa; es la llegada de una noche que devora la vieja razón del mundo" (Foucault 1985: 40).

19 Y que "no toma sus materiales de la imaginación, sino de la vida real, tal como se presenta en cualquier parte", según carta de Balzac a Frau von Hanska recogida en Villanueva (2004: 49).

20 Decimos "clásico" asumiendo la arqueología foucaultiana que postula un saber moderno que deja atrás las concepciones epistemológicas del saber clásico vigente hasta el siglo XVII. En concreto tomamos una idea de literatura de la página 77 (Foucault 1997: 77). 
volverá más oscura, incluso en los episodios felices ${ }^{21}$. Murena, en fin, pelea por que se recupere la envidia del presente respecto al futuro, y para ello aspira al apocalipsis en la escritura, "si todo está podrido, oí, hay que empezar de nuevo por la base" (Murena 1970: $15)$.

\section{Referencias bibliográficas}

Barthes, Roland. El grado cero de la escritura. Trad. Nicolás Rosa. Madrid: Siglo XXI, 2005.

Bauer, J. B. Diccionario de teología bíblica. Trad. Daniel Ruiz Bueno. Barcelona: Herder, 1967.

Benjamin, Walter. Discursos interrumpidos I. Trad. Jesús Aguirre. Buenos Aires: Taurus 1969.

Berlin, Isaiah. El mago del norte: J. G. Hamann y el origen del irracionalismo moderno. Trad. Juan Bosco Díaz-Urmeneta Muñoz. Madrid: Tecnos, 1997.

De Man, Paul. La ideología estética. Trad. Manuel Asensi y Mabel Richard. Madrid: Cátedra, 1998.

Derrida, Jacques. La escritura y la diferencia. Trad. Patricio Peñalver. Barcelona: Anthropos, 2012.

Eliade, Mircea. Herreros y alquimistas. Trad. E. T., revisión Manuel Pérez Ledesma. Madrid: Alianza, 2001.

Esteban García, Patricia. La palabra imprecisa de Héctor A. Murena en los márgenes del ensayo argentino contemporáneo. Tesis doctoral. Madrid: UCM, 2008

Foucault, Michel. Historia de la locura en la época clásica. Vol. I. Trad. Juan José Utrilla. México: Fondo de Cultura Económica, 1985.

-Las palabras y las cosas. Trad. Elsa Cecilia Frost. Madrid: Siglo XXI, 1997.

Goethe, J. W. Faust, Trad. Rafael Cansino Assens. Madrid: Aguilar, 1943.

Ighina, Domingo, "Murena, negación y comienzos de la Historia", Inti. Revista de literatura hispánica, $\mathrm{n}^{\circ} .52$ (otoño-primavera 2000), pp. 247-252.

Lacoste, Jean-Ives (dir.). Diccionario crítico de Teología. Trad. dirigida por Julio A. Pardos y J. Pérez de Tudela. Madrid: Akal, 2007.

Löwy, Michael. Walter Benjamin: aviso de incendio. Una lectura de las tesis "Sobre el concepto de historia”. Trad. Horacio Pons. México: Fondo de Cultura Económica, 2002.

Martínez Estrada, Ezequiel. Muerte y transfiguración de Martín Fierro. Tomo I. México: Fondo de Cultura Económica, 1958.

Mate, Reyes. Medianoche en la historia. Comentarios a las tesis de Walter Benjamin "Sobre el concepto de historia". Madrid: Trotta, 2006.

Murena, H. A. Homo atomicus. Buenos Aires: Sur, 1961.

-Los herederos de la promesa. Buenos Aires: Sur, 1965.

-Polispuercón. Buenos Aires: Sudamericana, 1970.

-Folisofía. Caracas: Monte Ávila, 1976.

— "Héctor A. Murena, a propósito de 'El sueño de la razón”", La Buraco, Buenos Aires, n’. 4 (diciembre de 1992), p. 20.

—Ensayos sobre subversión seguido de El nombre secreto.Barcelona: Octaedro, 2002a.

21 'La 'muerte' corresponde generalmente - en el nivel operatorio- al color negro que tomaban los ingredientes, a la nigredo. Y la reducción de las sustancias a la materia prima, a la masa confusa, la masa fluida, informe, que corresponde -en el nivel cosmológico- a la situación primordial, al caos. La muerte representa la regresión a lo amorfo, la reintegración del Caos" (Eliade 2001: 138). 
—Visiones de Babel. México: Fondo de Cultura Económica, 2002b.

-El pecado original de América. México: Fondo de Cultura Económica, 2006.

—Los penúltimos días. Edc. Patricia Esteban. Valencia: Pre-textos, 2012.

__El café", Espacio Murena: http://www.espaciomurena.com/?p=2849 (el 12/2/2014).

Rama, Ángel. La novela en América Latina: 1920-1980. Santiago de Chile: Universidad Alberto Hurtado, 2008.

Said, Edward. El mundo, el texto y el crítico. Trad. Ricardo García Pérez. Barcelona: Random House Mondadori, 2008.

Strauss, Leo. El renacimiento del racionalismo político clásico. Trad. Amelia Aguado. Buenos Aires: Amorrortu, 2007.

Trilling, Lionel. La imaginación liberal. Ensayos sobre la literatura y la sociedad. Trad. Enrique Pezzoni. Barcelona: Edhasa, 1971.

Wolin, Richard. Los hijos de Heidegger. Trad. María Cóndor Orduña. Madrid: Cátedra, 2003.

Los epígrafes están extraídos de "La sonrisa de Beatriz" en Ensayos Dantescos, de Jorge Luis Borges, y de la película Invasión (1969), cuyo guión escribieron J. L. Borges y Hugo Santiago Muchnick. 